\title{
Determinants of Government Characteristics and Audit Findings on Local Government Financial Performance
}

\author{
Febriana Dwi Jayanti \& Mahendro Sumardjo \\ Universitas Pembangunan Nasional Veteran Jakarta, Indonesia \\ febriana.jayantidwi@gmail.com
}

\begin{abstract}
This study is based on the low success of local governments' financial performance in West Java Province, as evidenced by the fact that financial reports of local governments that receive unqualified opinions are still being found. The detection of numerous frauds in local governments is responsible for the majority of incidents of poor financial performance in local governments. Local government financial performance is related to local government size, dependence on central government, local spending, and audit findings. The purpose of this study was to examine the influence of local government characteristics and audit findings on the financial performance of local governments. Techniques analyzing data used regression model selection test with STATA version 16. This study builds on agency theory to develop a conceptual framework that connects local government size, dependence on central government, local expenditure, audit findings, and financial performance. The results of this study show that the size of local government, local spending has a significant effect on local government financial performance based on independence ratio and operating expenditure activity ratio, local government financial performance is unaffected by the dependence of central government or audit findings. Contributions to the West Java Provincial Government are required to be taken into account when making decisions and policies for the improved financial performance of local government.
\end{abstract}

Keywords: Government Size, local expenditure, audit findings, the dependence of central government, financial performance.

\section{Introduction}

The public sector in Indonesia shows significant enthusiasm in the well-being of the community through, the various services provided, this is reflected in the number of local governments that actively realize the wellbeing of their regions by proving good annual performance reports. The public sector is a government entity with other organizational units, the unit in question is regional management to address the living needs of the people or a form of service to the community in the fields of health, education, and security (Halim, 2008). The high enthusiasm of the public sector in Indonesia is due to the implementation of various policies and development programs. In addition, the community demands local governments in terms of improving financial and non-financial performance through various more creative and innovative programs to optimize the various local potentials available. The development of government performance also develops implications for the complex services of government entities (Sesotyaningtyas, 2012). Therefore, the government must be responsible for reporting all activities carried out so that its performance can be evaluated by the parties concerned and also the community. If the government's performance is felt to have good implications for the development of public services, then the growth of positive value-added from investment is higher. Thus, encouraging infrastructure improvements, increasing Regional Income Allocation (PAD).

Increasing capital expenditure and intergovernmental revenue with management using regional independence ratio (Abdullah \& Halim, 2006). The financial information in the Local Government Financial Report (LKPD) or liability report is stated to have indicators measuring the financial performance of the local government in the current year (Junawati et al., 2013). However, it is unfortunate that the public is too high in assuming the performance of the government, which is due to the emergence of issues related to the highlight of government performance in the eyes of the public. One of the reasons is because the people feel they have not enjoyed the results of government performance to the maximum. The main issue is described as the number of LKPDs that have not yet presented reports properly in certain aspects so that the LKPD has not obtained a Fair With-out Exception (WTP) opinion. Despite this, it is known that during the last decade, the implementation of independence in Indonesia through fiscal decentralization has not worked to the maximum. Policy design and practice (performance) is one of the causes (Jaweng, 2014). The phenomenon of 
financial performance that occurs in Local Governments in Indonesia is revealed in various aspects. As in 2015 revealed by the BPK as many as 280 local governments in Indonesia experienced cases of asset management reaching 2,006 trillion is not optimal. Then continued the findings of fraud, cuts in social assistance, and embezzlement of BPJS funds in 2018 in the Government of West Java. Financial performance is the achievement of an organization in a certain period (Bastian, 2010). Based on the phenomenon that has been described previously, to strengthen the results of research in testing the influence on the financial performance, the researcher will conduct other research although some indicators have been studied previously. However, earlier research, such as that undertaken by Masdiantini and Erawati (2016), has shown that there is a link between the size of local government and its financial success. Meanwhile, Marfiana and Kurniasih (2013) stated that there is no effect between the size of local government with the financial performance of local government. The results of research by Noviyanti and Kiswanto (2016) and Suryaningsih and Sisdyani (2016) stated the influence between dependence on the central government with the financial performance of local governments. Meanwhile, Kusuma and Handayani (2017) and Aswar (2019) stated that there is no effect between dependence on the central government with the financial performance of local governments. Furthermore, Marfiana and Kurniasih (2013) and Kusuma and Handayani (2017) stated the influence.

Between regional spending and the financial performance of local governments. There is no correlation between regional spending and local government financial performance, according to Nugroho and Prasetyo (2018) and Dasmar, et al. (2020). Marfiana and Kurniasih (2013) stated the influence between the findings of the BPK audit with the financial performance of local governments. Meanwhile, Jannah et al. (2020), and Dasmar, et al. (2020) stated that there is no effect between the findings of the audit with the financial performance of local governments. The purpose of this study was to examine the influence of local government size, dependence on central government, local expenditure, and audit findings on financial performance. According to research recommendations made by Aswar (2019) and Wijayanti and Suryandari (2020), this study adds the variable of central government dependency as an indicator of local government independence, as well as the audit findings as an indicator of regulatory compliance. This research has extensive implications for inspectorates and regional apparatus, public sector practitioners, and public sector auditors, in addition to the theoretical benefits.

\section{Literature Review and Hypothesis Development}

Agency Theory: Due to the existence of a contract for the agent to act for and on behalf of the principal in making a decision, agency theory maintains that the theoretical relationship between the principal as the owner of the power and the agent is management as the executor of the authority. Agency theory in the government sector is used as an analysis of principal-agent relationship when making public sector budgeting due to the contract in terms of providing services (services) as the principal's interest, in it also states the role of parties in the public sector. The role of each party involved, among others, the first party auditor of the Financial Examining Agency as an examiner of performance and financial reports for the current period, the second party auditee/client/entity examined as the manager and responsible for State Finance such as: central and local governments (Ministry / Institutions, public service bodies), State-Owned Business Entities, Regional -Owned Usama Bodies, third party recipients/ external users such as representative institutions, as well as the public in accordance with the Public Information Disclosure Act (Rai, 2008). The community trusts the government to manage local revenue and develop policies to give welfare to the community, as evidenced by this study's relationship with agency theory.

Hypothesis and Conceptual Framework: The following are the hypotheses that have been developed in this study based on elements that are likely to affect the financial performance of local governments:

Government Size and Financial Performance: The size of a local government is determined by taking into account all total assets, total revenue, the number of employees, and service production levels (Damanpour, 1991). In terms of financial performance, it is predicted that greater size will improve the region's financial performance and vice versa. Masdiantini and Erawati (2016), Andani et al. (2019), and Islami et al. (2020) investigated the impact of local government size on the financial performance of local governments. 
According to a previous study, the size of a local government has a significant impact on its financial success. H1: local government size has a significant effect on the financial performance of the local government.

Dependence of Central Government and Financial Performance: The size of the General Allocation Fund reflects the level of reliance on the central government (GAF). GAF is a fund derived from the central government's State Revenue and Expenditure Budget (APBN) and distributed to local governments as a form of decentralization support (Central Government, 2005). Marfiana and Kurniasih (2013), Aziz (2016), and Noviyanti and Kiswanto (2016) investigated the impact of reliance on the central government on financial performance. Previous research has found that a local government's reliance on the federal government has a major impact on its financial success.

H2: dependence on the central government has a significant effect on the financial performance of local governments.

Local Expenditure and Financial Performance: Regional expenditure based on Law Number 32 of 2004 is a regional obligation that is recognized as a reduction in the value of net wealth in the current budget period (Central Government, 2004). It is intended to meet the needs in the implementation of public services. Marfiana and Kurniasih (2013), Aziz (2016), and Noviyanti and Kiswanto (2016) investigate the impact of regional spending on local government financial performance. According to a previous study, regional spending has a significant impact on local government financial performance.

H3: local expenditure has a significant impact on the financial performance of local governments.

Audit Findings and Financial Performance: Audit findings are conditions related to statements of fact (Bastian, 2014). By complying with all the prescribed laws and regulations, the government's performance will be better because the findings stated by the auditors will be few and even indicated not at all. Renas and Muid (2014), Masdiantini and Erawati (2016), and Noviyanti and Kiswanto (2016) investigate the impact of BPK audit results on local government financial performance. According to previous research, the audit's conclusions have a significant impact on local governments' financial performance.

H4: Audit findings have a significant impact on the financial performance of local governments.

\section{Figure 1: Research Framework}

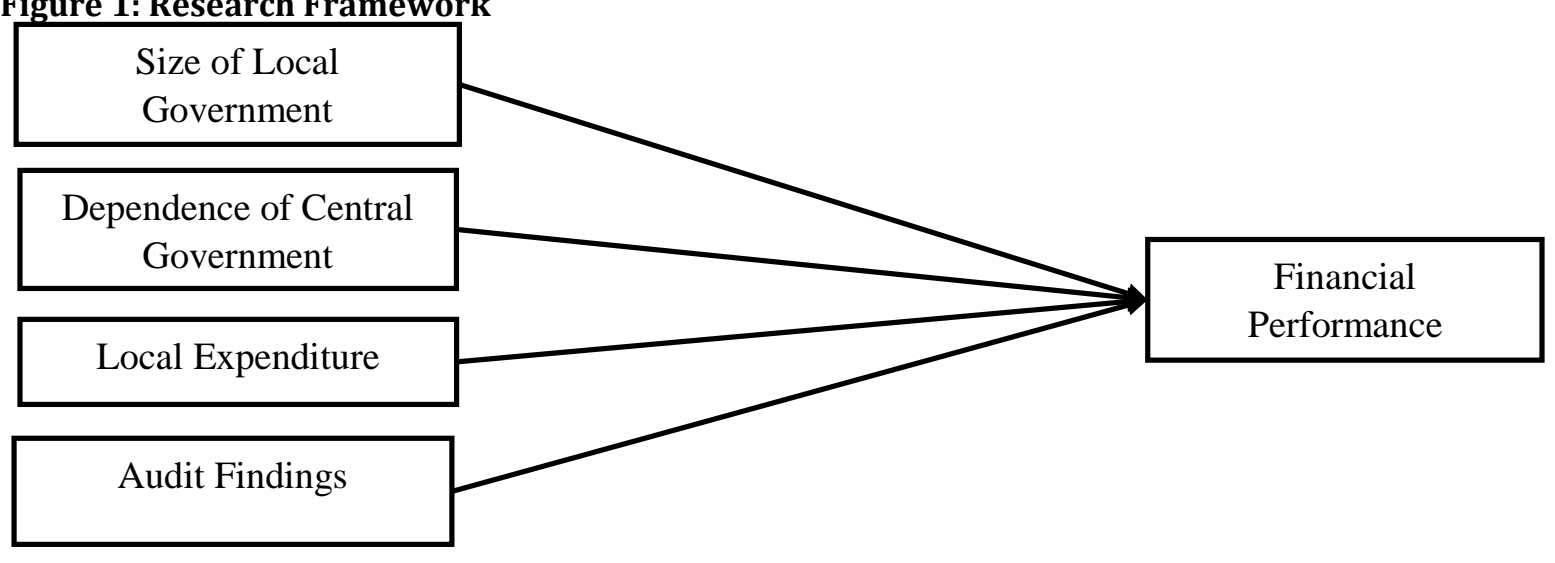

\section{Research Methodology}

The population of the study is comprised of the district/city governments in West Java Province, which consists of 18 district governments and 9 city administrations. Secondary data in the form of local government financial reports (LKPD) and inspection reports audited by the BPK RI in West Java Province from 2017 to 2019 was used in the research. This study uses the multiple linear regression hypothesis techniques by STATA application. This study uses ratio and nominal scales. This study employed 72 samples out of a total of 81 samples that were evaluated according to the researchers' criteria. The following are the criteria that were employed in this sampling process:

- Local Governments in West Java Province and LKPD from 2017 to 2019 have been audited. The report has been uploaded on the official website of the BPK RI. 
- LKPD provided by the local government is complete for the research period, LKPD obtained by the researcher through the page https://www.bpk.go.id/

- LKPD is loaded in full such as Balance Sheet, Budget Realization Report, Operational Report, Cash Flow Report, Equity Change Report, and Notes on Financial Statements.

- Have data on the report of the results of the audit examination in 2017 to 2019 to obtain the number of audit findings.

Table 1: Measurement of Variables

\begin{tabular}{|c|c|c|}
\hline Variable & Measurement & Source \\
\hline $\begin{array}{l}\text { Financial } \\
\text { performance }\end{array}$ & $\begin{array}{l}\text { Five regional financial ratios are used to assess the financial } \\
\text { performance of local governments. These include revenue } \\
\text { effectiveness ratios, efficiency ratios, independence ratios, } \\
\text { activity ratios, and growth ratios for municipal. }\end{array}$ & $\begin{array}{l}\text { (Halim \& Kusufi, } \\
\text { 2012) }\end{array}$ \\
\hline $\begin{array}{l}\text { Size of local } \\
\text { government }\end{array}$ & Ln total assets in the local government balance sheet & (Tama \& Adi, 2018) \\
\hline $\begin{array}{l}\text { Dependence of } \\
\text { central government } \\
\text { Local expenditure }\end{array}$ & $\begin{array}{l}\text { Comparison between General Allocation Fund to total } \\
\text { income. } \\
\text { Ln total realization of regional spending. }\end{array}$ & $\begin{array}{ll}\text { (Marfiana } & \& \\
\text { Kurniasih, 2013) } & \\
\text { (Kusuma } & \& \\
\text { Handayani, 2017) } & \end{array}$ \\
\hline Audit findings & Audit findings in Rupiah & (Tama \& Adi, 2018) \\
\hline
\end{tabular}

\section{Results and Discussion}

In West Java Province, there are 81 district and city administrations that make up the population of this research. Purposive sampling is a strategy for selecting samples. Table 2 shows the final sample of this investigation.

Table 2: Final Sample of the Study

Criteria $\quad$ Total

Local Governments in West Java Province and LKPD from 2017 to 2019 have been audited. The 27 report has been uploaded on the official website of the BPK RI

LKPD provided by the local government is complete for the research period, LKPD obtained by the researcher through the page https://www.bpk.go.id/

LKPD is loaded in full such as Balance Sheet, Budget Realization Report, Operating Report, Cash Flow Report, Equity Change Report and Notes on Financial Statements.

Data on the report of the results of the audit examination in 2017 to 2019 to obtain the number of audit findings

The company did not meet the required data

The number of governments that are the sample of the study

Number of research periods

27

al

Number of samples during the study period

Based on the criteria established for selecting the sample for this study, a sample was chosen from the total population of 27 Regional Governments in the Province of West Java between 2017 and 2019, based on the criteria established. The selection was conducted on 3 (three) local governments that did not meet the research data completely for the research period, namely 2017 to 2019 . The results obtained are the total sample in this study amounted to 72 samples. 
Table 3: Statistical Descriptive Analysis

\begin{tabular}{llllll}
\hline Variable & Obs & Mean & Std Deviation & Min & Max \\
\hline EFFECTPAD_w & 72 & 0,9752968 & 0,1196052 & 0,5665126 & 1,332647 \\
EFFIC_w & 72 & 4,27895 & 1,858874 & 1,498789 & 9,528152 \\
INDEPD_w & 72 & $-0,0513549$ & 0,1940351 & $-0,2807342$ & 0,4504358 \\
EXPDOP_w & 72 & 0,7715067 & 0,1080756 & 0,0879946 & 0,8885168 \\
EXPDCAP_w & 72 & 0,2019972 & 0,0634702 & 0,0119598 & 0,3967461 \\
GRWTH_w & 72 & 0,1231229 & 0,2761219 & $-0,391411$ & 0,8568515 \\
SIZE_w & 72 & $5,35 \mathrm{e}+12$ & $4,79 \mathrm{e}+12$ & $4,75 \mathrm{e}+10$ & $2,65 \mathrm{e}+13$ \\
DEPEND_w & 72 & 0,3933705 & 0,0602894 & 0,2141489 & 0,4848885 \\
EXPENDIT_w & 72 & $3,13 \mathrm{e}+12$ & $2,69 \mathrm{e}+12$ & $7,26 \mathrm{e}+11$ & $2,21 \mathrm{e}+13$ \\
FNDGS_w & 72 & $8,89 \mathrm{e}+09$ & $1,57 \mathrm{e}+10$ & $-2,97 \mathrm{e}+09$ & $7,27 \mathrm{e}+10$ \\
\hline
\end{tabular}

Based on the purposive sampling method, the sample size is 81 consisting of 27 districts/cities during the period of 3 years of research, but after the elimination of outlier data into 72 samples used in this study. The independent variable of local government size has an average value of $5.35 \mathrm{e}+12$, dependence on central government has an average value of 0.3933705 , regional spending has an average value of $3.13 \mathrm{e}+12$, and audit findings have an average value is $8.89 \mathrm{e}+09$. While the dependent variable of local government financial performance with PAD effectiveness ratio proxy has an average value of 0.9752968 , efficiency ratio has an average value of 4.27895 , independence ratio has an average value of -0.0513549 , operating expense activity ratio has a value an average of 0.7715067 , the capital expenditure activity ratio has an average value of 0.2019972 , and the growth ratio has an average value of 0.1231229 .

Table 4: Stata Analysis Results

\begin{tabular}{|c|c|c|c|c|c|c|c|c|c|c|c|c|}
\hline & \multirow{2}{*}{\multicolumn{2}{|c|}{$\begin{array}{l}\text { Model 1 } \\
\text { EFFECT } \\
\text { PAD }\end{array}$}} & \multirow{2}{*}{\multicolumn{2}{|c|}{$\begin{array}{l}\text { Model } 2 \\
\text { EFFIC }\end{array}$}} & \multirow{2}{*}{\multicolumn{2}{|c|}{$\begin{array}{l}\text { Model } 3 \\
\text { INDEPD }\end{array}$}} & \multirow{2}{*}{\multicolumn{2}{|c|}{$\begin{array}{l}\text { Model } 4 \\
\text { EXPENDOP }\end{array}$}} & \multirow{2}{*}{\multicolumn{2}{|c|}{$\begin{array}{l}\text { Model } 5 \\
\text { EXPENDCAP }\end{array}$}} & \multicolumn{2}{|c|}{$\begin{array}{l}\text { Model } 6 \\
\text { GRWTH }\end{array}$} \\
\hline & & & & & & & & & & & GRW & \\
\hline & $\mathrm{Z}$ & $\mathrm{P}>|\mathrm{z}|$ & $\mathrm{T}$ & $\mathrm{Z}$ & $\mathrm{P}>|\mathrm{z}|$ & $\mathrm{Z}$ & $\mathrm{P}>|\mathrm{z}|$ & $\mathrm{T}$ & $\mathrm{P}>|\mathrm{t}|$ & $P>|t|$ & $\mathrm{Z}$ & $\mathrm{P}>|\mathrm{z}|$ \\
\hline SIZE_w & 1,18 & 0,237 & 1,03 & 3,60 & 0,000 & 0,68 & 0,497 & 0,02 & 0,984 & 0,311 & 2,38 & 0,018 \\
\hline DEPEND_w & 0,99 & 0,322 & $-0,43$ & 1,88 & 0,060 & $-1,34$ & 0,179 & $-0,32$ & 0,748 & 0,672 & $-1,32$ & 0,188 \\
\hline EXPENDIT_w & 1,10 & 0,273 & 1,21 & $-6,04$ & 0,000 & $-2,34$ & 0,019 & $-0,43$ & 0,665 & 0,231 & $-1,17$ & 0,241 \\
\hline $\begin{array}{l}\text { FNDGS_w } \\
\mathrm{N}: 72\end{array}$ & 0,37 & 0,715 & 0,01 & $-1,17$ & 0,243 & 2,27 & 0,023 & 0,16 & 0,872 & 0,995 & 0,31 & 0,755 \\
\hline
\end{tabular}

Based on the results of the data in this study, that SIZE shows z-count $<$ z-value $(1.18<1.96)$ and significance value $(0.237>0.05)$ in model 1 . Then $t$-count $<t$-table $(1.03<1.96)$ and significance value $(0.311>0.05)$ in model 2 . Then $\mathrm{z}$-count $<\mathrm{z}$-value $(0.68<1.96)$ and significance value $(0.497>0.05)$ in model 5 . And z-count $<\mathrm{z}$ value $(0.02<1.96)$ and a significance value $(0.984>0.05)$ in model 6 . The proposed hypothesis is rejected. The findings of this study agree with those of Nugroho and Prasetyo (2018) and Maulina, et al. (2021), who found that the size of local governments had little bearing on their financial success. According to the findings, the proposed hypothesis is rejected, and the agency theory, which states that local governments are given authority to manage assets for public use, is not supported. In fact, government assets have not been fully managed optimally in meeting the needs of public activities and services as well as the needs of each region is difficult to estimate. Other results from this research data show that SIZE shows z-count $>$ z-value $(2.38>1.96)$ and significance value $(0.018<0.05)$ in model 3 . And $z$-count $>z$-value $(3.60>1.96)$ and significance value $(0.000<0.05)$ in model 4 . As a result, it can be deduced that the size of a local government affects its financial performance, and the hypothesis is supported.

The findings of this research back up those of Aziz (2016) and Masdiantini and Erawati (2016), who discovered that the size of a local government has a significant positive impact on its financial success, The outcomes of this study support the agency theory, which argues that local governments have been able to maximize government operations related to their performance by using good asset management to benefit their principles. DEPEND exhibits a t-count t-table $(0.991 .96)$ and significance value $(0.322>0.05)$ in model 1 
based on the outcomes of the data in this study. Then t-count $<\mathrm{t}$-table $(-0.43<1.96)$ and a significance value $(0.672>0.05)$ in model 2 . Then $\mathrm{t}$-count $<\mathrm{t}$-table $(-1.32<1.96)$ and a significance value $(0.188>0.05)$ in model 3 . Then $\mathrm{t}$-count $<\mathrm{t}$-table $(1,88<1.96)$ and significance value $(0.060>0.05)$ in model 4 . As well as $\mathrm{z}$-count $<\mathrm{z}$ value $(-1.34<1.96)$ and significance value $(0.179>0.05)$ in model 5 . Last count $<\mathrm{t}$-table $(-0.32<1.96)$ and significance value $(0.748>0.05)$ in model 6 . As a result, It can be deduced that local governments' financial performance is unaffected by their reliance. On the federal government, and the presented hypothesis is rejected. The findings of this analysis agree with those of Kusuma and Handayani (2017) and Aswar (2019).

They discovered that local government financial performance was unaffected by reliance on the federal government. The findings of this investigation showed that the hypothesized hypothesis was rejected and that agency theory was not supported which said that general allocation funds and revenues of each region should be allocated for decentralization and equitable growth, but the needs of each region are different and their management is not optimal for regional needs, there are still many funds used for other purposes outside the principal's interests. EXPENDIT has a z-count z-value $(1.101 .96)$ and a significant value $(0.273>$ $0.05)$ in model 1 . Then $t$-count $<$ t-table $(1.21<1.96)$ and significance value $(0.231>0.05)$ in model 2 . Then count $<$ z-value $(-1.17<1.96)$ and significance value $(0.241>0.05)$ in model 3 . And calculate $<$ table $(-0,43$ $<1.96)$ and a significance value $(0.665>0.05)$ in model 6 . As a result, it is reasonable to conclude that municipal spending has no bearing on the financial success of local governments. The presented hypothesis is rejected. The findings of this study agree with those of Nugroho \& Prasetyo (2018) and Dasmar, et al. (2020), who found that regional spending had no substantial impact on local government financial performance.

The proposed hypothesis is rejected, and the agency theory, which states that while the authority in the management of regional expenditure is required to meet the needs of regions in providing public services, increases in nominal capital expenditure and increases in the proportion of capital expenditure are not mutually exclusive, is not supported, according to the findings of this study. Other results from this research data show that EXPENDIT shows $z$-count $<$ z-value $(-6.04>1.96)$ and a significance value $(0.000<0.05)$ in model 4. Last $\mathrm{z}$-count $<\mathrm{z}$-value $(-2.34>1,96)$ and a significance value $(0.019<0.05)$ in model 5 . As a result, it may be inferred that regional expenditure has an impact on local government financial performance, but not in the way that the hypothesis predicted, regional spending has a major negative impact. The findings of this study agree with those of Ariwibowo (2016) and Qowi and Prabowo (2017), who found that regional spending had a considerable negative impact on local government financial performance. These findings contradict the study's hypothesis, which suggested that municipal spending has a positive impact, on the financial success of local governments.

The bigger the government entity's expenditure, the better the region's financial success, yet this cannot be verified, according to this agency's opinion. In the context of the connection between the principal and agent, there is a tendency to commit moral hazard in order to maximize its utility. So that in the process of budgeting regional expenditure funds can allow the occurrence of inequality between the amount of expenditure budgeted is not able to reflect the actual ability of regional spending. FNDGS reveals z-count zvalue $(0.371 .96)$ and significant value $(0.715>0.05)$ in model 1 . Then $t$-count $<t$-table $(0.01<1.96)$ and significance value $(0.995>0.05)$ in model 2 . Then $z$-count $<z$-value $(0.31<1.96)$ and significance value $(0.755>0.05)$ in model 3 . While $z$-count $<z$-value $(-1.17<1.96)$ and significance value $(0.243>0.05)$ in model 4. Finally, t-count $<$ t-table $(0.16<1.96)$ and significance value $(0.872>0.05)$ in model 6 . As a result, the audit findings had no bearing on the financial performance of local governments, and the theory was disregarded. The findings of this study are consistent with those of Jannah et al. (2020) and Dasmar et al. (2020), who found those audit findings had no substantial impact on financial performance.

According to the findings, the proposed hypothesis was rejected, and the agency theory, which claimed that local governments should make financial records and audited reports more transparent in order to strengthen public control over government, was dismissed. Nevertheless, the number of audit findings does not play a direct role in financial performance because the agent does not apply the criticisms and suggestions from the auditor properly. Other results from the data of this study show that FNDGS z-count > zvalue $(2.27>1.96)$ and significance value $(0.023<0.05)$ in model 5 . As a result, it's possible to deduce that the audit findings have an impact on local government financial performance, but not in the way that the hypothesis of a substantial positive impact suggests. These findings contradict the study's hypothesis, which 
suggested that audit findings have a negative influence on the financial performance of local governments. Local officials should follow the laws and regulations in carrying out their duties so as not to give rise to a finding in providing services to principals; the greater the number of findings of breaches of compliance from related entities, the lower the financial performance of local governments.

\section{Conclusion and Recommendations}

Based on the ratio of independence and capital spending activities, the size of local government has a considerable favorable effect on its financial performance. This shows that if there is an increase or decrease in the size of local government then the financial performance of local government also experiences the same thing. The size of the local government does not have a significant effect on the financial performance of the local government based on the ratio of local revenue effectiveness, efficiency, capital spending activities and growth. This means that if the size of local government grows or shrinks, the financial performance of the government does not change, implying that the size of local government has no bearing on its financial success. This is due to the fact that the asset function has not been fully utilized for productive tasks. Local governments' financial success is unaffected by their reliance on the federal government. This means that whether the level of reliance on the central government rises or falls, the financial performance of local governments does not suffer in the same way, implying the opposite of reliance on the central government. This is because, while the factors of general allocation funds and total revenue influence regional financial performance, it is still implemented in line with the right budget. Furthermore, general allocation funds are misappropriated to conduct routine shopping, resulting in a lack of targeting. Based on the activity ratio, local expenditure has a major negative impact on local government financial performance. This means that if local expenditure increases or decreases; the financial performance is affected in the same way.

Based on the ratios of local revenue effectiveness, efficiency, independence, and growth, local expenditure has no substantial impact on the financial performance of local governments. This means that if regional spending increases or decreases, local government financial performance does not change in the same way, therefore it is the opposite of regional spending. This is because regional expenditure incurred by the government in each entity is not for financing activities that are declared productive such as capital expenditure in the form of land to be managed as a source of regional income and for improving regional infrastructure in the long run but the budget is used to meet employee expenditure, meaning only to satisfy the local officials. The findings of the audit had a significant positive effect on the financial performance of local governments based on the ratio of capital expenditure activities and concluded that the results contradicted the research hypothesis. The findings of the audit did not have a significant effect on the financial performance of local governments based on the ratios of local revenue effectiveness, efficiency, independence, operating spending activity and growth.

This indicates that if there is an increase or decrease in the findings of the audit, then the financial, performance of local governments do not experience the same thing, thus contrary to the findings of the audit. This is because the presence of many audit findings in the government does not always imply poor financial performance by local governments. The financial performance of entities that have been implemented into various activities is unaffected by large or small audit findings because if you want to know the number of findings, you must confirm further from the perspective of performance assessment after the audit LKPD. West Java is expected to provide consideration in making decisions and policies on the development of local government financial performance. Then, for future research, other variables not explored in this study, such as regional wealth, legislative size, and audit opinion, are likely to be used as well as further researchers are expected to conduct research on government entities other than the Province of West Java that has not been studied by adding a period of research years. 


\section{References}

Abdullah, S. \& Halim, A. (2006). Studi atas Belanja Modal pada Anggaran Pemerintah Daerah dalam Hubungannya dengan Belanja Pemeliharaan dan Sumber Pendapatan. SSRN Electronic Journal, 2(2), 17-32.

Afia Maulina, Mustafa Alkamal, N. S. F. (2021). Pengaruh Pendapatan Asli Daerah, dana Perimbangan, Belanja Modal, Dan Ukuran Pemerintah Daerah Terhadap Kinerja Keuangan Pemerintah daerah. Journal of Information System, Applied, Management, Accounting and Research, 5(2), 390-399.

Andani, M., Sarwani, S. \& Respati, N. W. (2019). Pengaruh Karakteristik Pemerintah Daerah Dan Opini Audit Terhadap Kinerja Pemerintah Provinsi Di Indonesia. Jurnal Akuntansi, 9(2), 111-130.

Ariwibowo, T. (2016). Pengaruh Dana Permbangan Dan Belanja Daerah Terhadap Kinerja Keuangan Dengan Pendapatan Asli Daerah Sebagai Variabel Moderasi. Jurnal Akuntansi dan Sistem Teknologi Informasi, 11(khusus), 335-344.

Aswar, K. (2019). Financial Performance of Local Governments in Indonesia. European Journal of Business and Management Research, 4(6), 1-6.

Aziz, A. (2016). Pengaruh Karakteristik Pemerintah Daerah Terhadap Kinerja Keuangan Pemerintah Daerah Kabupaten \& Kota Di Jawa Timur. Assets: Jurnal Akuntansi dan Pendidikan, 11(1), 27.

Bastian, I. (2010). Akuntansi Sektor Publik Suatu Pengantar (3 ed.). Erlangga.

Bastian, I. (2014). Audit Sektor Publik Pemeriksaan Pertanggungjawaban Pemerintahan (3 ed.). Salemba Empat.

Central Government. (2004). Undang-Undang Nomor 32 Tahun 2004. Undang-Undang, 1-177.

Damanpour, F. (1991). Organizational Innovation: A Meta-Analysis Of Effects Of Determinants And Moderators. Academy of Management Journal, 34(3), 555-590.

Dasmar, T., Yesi, M. \& Basri, N. I. (2020). Pengaruh Kekayaan Daerah, Belanja Daerah, Inergovernmental Revenue, Temuan Audit Terhadap Kinerja Pemerintah Daerah. Jurnal Al Iqtishad, 16(2), 39-57.

Halim, A. (2008). Akuntansi Sektor Publik Akuntansi Keuangan Daerah (R. Widyaningrum (ed.); 3 ed.). Salemba Empat.

Halim, A. \& Kusufi, A. (2012). Akuntansi Sektor Publik: Akuntansi Keuangan Daerah. Salemba Empat.

Islami, A. Y. \& Edwin, F. \& Riana. M. (2020). Factors influencing the financial performance of south Sumatra Province local government for the period 2012-2016. Journal of Critical Reviews, 7(15), 2115-2124.

Jannah, M., Azwardi. \& Siddik, S. (2020). The effect of BPK audit result on financial performance. Accounting, 6(7), 1253-1258.

Jaweng, R. E. (2014). Analisis CSIS: Pemekaran daerah Dan Problem Representasi Politik. Analisis CSIS, 43(1), 43-63.

Junawati, J. \& Hasan, B. S. A. (2013). Pengaruh Pendapatan Asli Daerah Terhadap Kinerja Keuangan Daerah Pada Kabupaten/Kota Di Provinsi Aceh Tahun 2010-2012. Jurnal Telaah dan Riset Akuntansi, 6(2), 186-193.

Kusuma, A. R. (2017). Pengaruh Karakteristik Pemerintah Daerah Terhadap Efisiensi Kinerja Keuangan Pemerintah Daerah. Jurnal Ilmu dan Riset Akuntansi, 6(1), 404-420.

Masdiantini, P. R. \& Erawati, N. A. (2016). Pengaruh Ukuran Pemerintah Daerah, Kemakmuran, Intergovernmental Revenue, Temuan Dan Opini Audit Bpk Pada Kinerja Keuangan. E-Jurnal Akuntansi, 14(2), 1150-1182.

Muid, R. D. (2014). Pengaruh Karakteristik Pemerintah Daerah dan Temuan Audit BPK Terhadap Kinerja Pemerintah Daerah Studi pada Pemerintah Daerah Kabupaten/Kota di Provinsi Jawa Tengah Periode 2009-2011. Diponegoro Journal of Accounting, 4(3), 1-15.

Nandhya Marfiana, L. K. (2013). Pengaruh Karakteristik Pemerintah Daerah dan Hasil Pemeriksaan Audit BPK Terhadap Kinerja Keuangan Pemerintah Daerah Kabupaten/Kota. Bongaya Journal for Research in Accounting (BJRA), 1(2), 51-55.

Nugroho, T. \& Prasetyo, N. E. (2018). Pengaruh Karakteristik Pemerintah Daerah Terhadap Kinerja Keuangan Pemerintah Daerah Kabupaten \& Kota Di Jawa Timur. Assets: Jurnal Akuntansi dan Pendidikan, 7(1), 27-34.

Nur Ade Noviyanti, K. (2016). Pengaruh Karakteristik Pemerintah Daerah, Temuan Audit BPK Terhadap Kinerja Keuangan Pemerintah Daerah. Accounting Analysis Journal, 5(1), 1-10.

Qowi, R. \& Prabowo, T. J. W. (2017). Pengaruh Karakteristik Pemerintah Daerah Dan Temuan Pemeriksaan BPK Terhadap Kinerja Pemerintah Daerah Kabupaten/Kota Di Indonesia Tahun Anggaran 2012. 
Diponegoro Journal of Accounting, 6(1), 1-13.

Rai, I. G. A. (2008). Audit Kinerja Pada Sektor Publik: Konsep, Praktik, dan Studi Kasus (P. Wuriarti (ed.)). Salemba Empat.

Sesotyaningtyas, M. (2012). Pengaruh Leverage, kuran Legislatif, Intergovernmental Revenue dan Pendapatan Pajak Daerah Terhadap Kinerja keuangan Pemerintah Daerah. Accounting Analysis Journal, 1(1), 1-6.

Suryaningsih, N. \& Sisdyani, E. (2016). Karakteristik Pemerintah Daerah Dan Opini Audit Pada Kinerja Keuangan Pemerintah Daerah. E-Jurnal Akuntansi, 15(2), 1453-1481.

Tama, I. G. M. A. A. \& Adi, P. H. (2018). Pengaruh Karakteristik Kepala Daerah, Ukuran Pemerintah, dan Temuan Audit terhadap Kinerja Keuangan Daerah. Perspektif Akuntansi, 1(1), 91-113.

Wijayanti, Y. \& Suryandari, D. (2020). The Effect of Regional Characteristics, Leverage, Government Complexity, BPK Audit Findings and Opinions on Local Government Financial Performance. Accounting Analysis Journal, 9(1), 30-37. 